\title{
A first probable case of SARS-CoV-2 reinfection in Colombia
}

\author{
Whilken Novoa ${ }^{1}$, Hollman Miller', Salim Mattar², Álvaro A. Faccini-Martínez², Ricardo Rivero² \\ and Hector Serrano-Coll ${ }^{2}$
}

\begin{abstract}
Although reinfection by SARS-CoV-2 is a rare phenomenon, cases with suspected or possible reinfection by SARS-CoV-2 have recently been reported in different countries. In some cases, it is not clear whether the individual's RT-qPCR test remained positive for a prolonged period after the first episode of infection or whether it represents true reinfection. The duration of viral RNA is variable in samples from the upper respiratory tract; RNA has been detected up to 104 days after the onset of symptoms [1]. To date, 8 cases of reinfection have been reported, 2 in India, one in Hong Kong, Belgium, Nevada, Ecuador, and the Netherlands. It is not clear why reinfections occur, but it could be due to the decrease in antibody levels, which are more decreased in asymptomatic patients, although in the eight patients reported so far, 4 had symptoms, and one was hospitalized [1].

This study describes the first probable case of SARSCoV-2 reinfection in Colombia. On June 26, 2020, a 44-year-old male patient, immunocompetent, without comorbidities, a health care worker had contact with a symptomatic relative with a positive RT-qPCR test (Fig. 1). On July 2, the patient and his family underwent RT-qPCR testing from nasopharyngeal specimens, giving a positive result for SARS-CoV-2 (Cq 36.89). He and his family remained asymptomatic. Then, on July 18 , a new RT-qPCR test was performed, and the result was negative (Fig. 1). On September 17, the patient underwent an antigen test required for a domestic flight in Colombia; the result was negative. On September 20, the patient
\end{abstract}

\footnotetext{
*Correspondence: mattarsalim@hotmail.com; mattarsalim@gmail.com

${ }^{2}$ Universidad de Cordoba, Instituto de Investigaciones Biologicas del Tropico, Monteria, Colombia
}

Full list of author information is available at the end of the article moved from the first place of infection $500 \mathrm{~km}$ away to another municipality bordering Brazil. $\mathrm{He}$ is a health care worker involved in public health activities related to the COVID-19 pandemic. On October 11, the patientreported symptoms such as malaise, chills, headache, fever, and odynophagia. Afterward, on October 15, oropharyngeal and nasopharyngeal samples were taken for antigen detection and RT-qPCR testing, respectively; both tests were positive. No samples were taken from the patient to other respiratory viruses complex because they are not performed routinely in patients with COVID-19. On October 26, the patient continued with symptoms and recovered at home (Fig. 1).

Although next-generation sequencing was not carried out to establish the phylogenetic patterns of the two strains in this report, the case shows that reinfection is possible in Colombia and that probably the duration of the antibodies is shorter than expected [2]. That was shown by Liu et al. [3], who showed that specific antibodies against SARS CoV2 disappeared three months after the symptoms' onset. Long et al. [4] also evidenced that in asymptomatic antibodies neutralizing decline in $40 \%$ of the asymptomatic individuals. Furthermore, epidemiological links show that reinfection could be occurring in different parts of Colombia, where the press has reported anecdotal cases. Although the present case does not have a genetic analysis of the virus, it suggests a strong epidemiological and microbiological result. The obtaining of two RT-qPCR test positive results at different times, cities and laboratories, shows that we may be facing a case of reinfection in Colombia.

Furthermore, a negative sample was obtained a month before the second RT-qPCR, and the case is linked to a

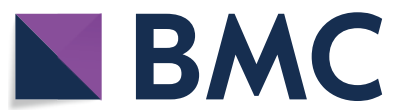

(c) The Author(s) 2021. This article is licensed under a Creative Commons Attribution 4.0 International License, which permits use, sharing, adaptation, distribution and reproduction in any medium or format, as long as you give appropriate credit to the original author(s) and the source, provide a link to the Creative Commons licence, and indicate if changes were made. The images or other third party material in this article are included in the article's Creative Commons licence, unless indicated otherwise in a credit line to the material. If material is not included in the article's Creative Commons licence and your intended use is not permitted by statutory regulation or exceeds the permitted use, you will need to obtain permission directly from the copyright holder. To view a copy of this licence, visit http://creativeco mmons.org/licenses/by/4.0/. The Creative Commons Public Domain Dedication waiver (http://creativecommons.org/publicdomain/ zero/1.0/) applies to the data made available in this article, unless otherwise stated in a credit line to the data. 


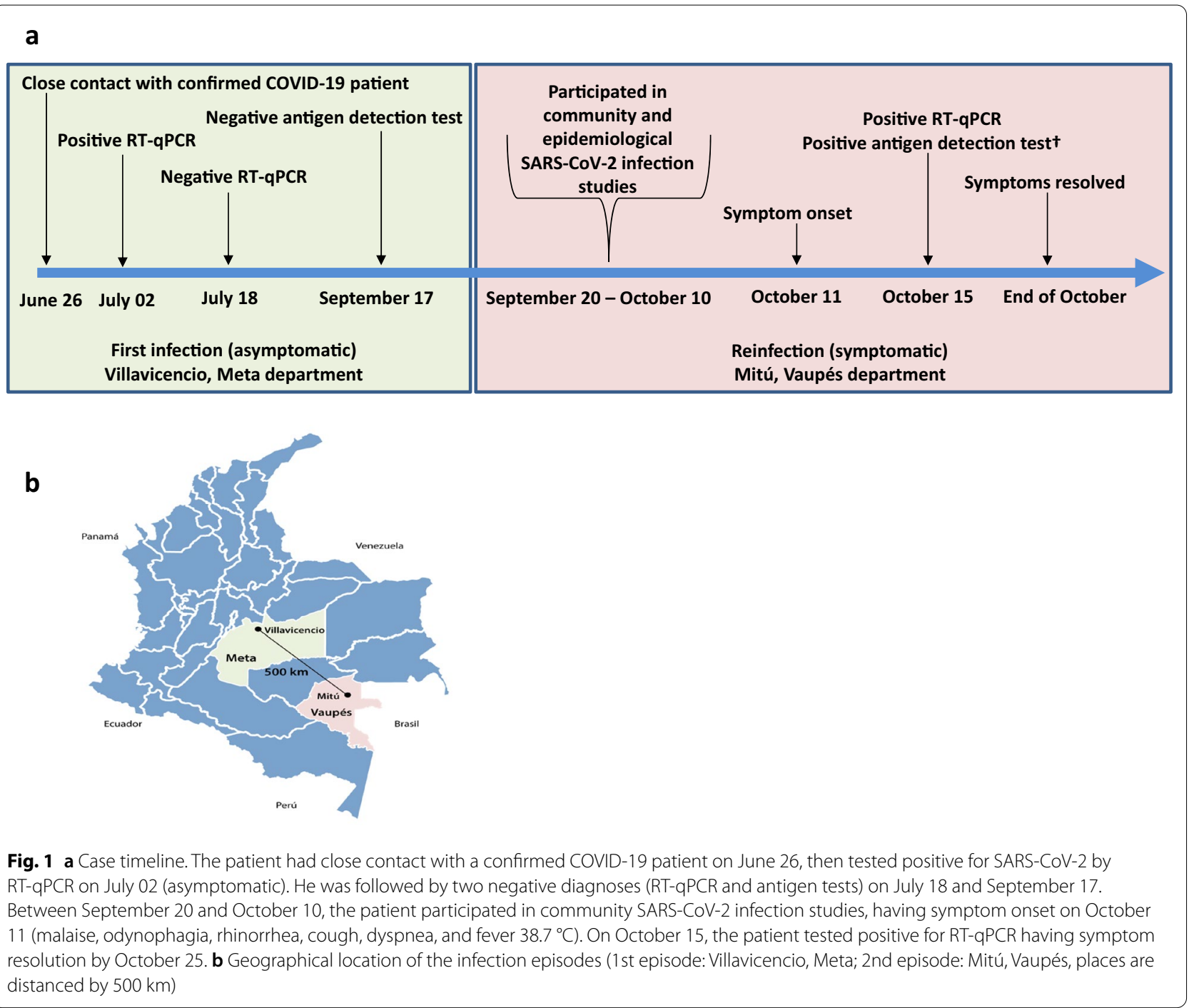

health care worker who is at daily risk. Unfortunately, we do not have the Cq value of the second RT-qPCR, which is a limitation of our work. On the other hand, transient immunity represents a warning for those health care workers who have been previously infected. However, it is relevant to mention that the risk of reinfection in this population would be low, given that the rate of infection by SARS-CoV2 in health workers is around $10 \%[5,6]$. Whereas, serology is not carried out in Colombia on a routine basis because the country has more than 1,270,991 cases, and its health system is resisting with limited resources the push of this first peek of the pandemic. Currently, the fatality rate reaches $2.81 \%$ (35.680/1.270.991), and although there is a decrease in cases in some departments, the increase in Colombia's number of cases is significant in epidemiological terms.
On the other hand, we have a second hypothesis that the patient was reinfected by another strain of SARS$\mathrm{CoV} 2$, given that his new infection occurred in a municipality near Brazil, although we cannot assure that it is a genetically different virus. A study conducted in the northern area of Brazil found a patient infected with a virus variant from lineage $\mathrm{A}$. This variant had a total of 9 mutations in comparison to the reference genome (NC_045512.2), being 4 of them non-silent mutations $[7,8]$. Nonetheless, phylogenetic analysis in Colombia showed that patients from the Meta department (location of the first episode) were infected with a virus belonging to lineage B1 [6]. Mutant viruses due to variations in spike protein have been found to evade neutralizing antibodies [9].

Finally, previous exposure to SARS-CoV-2 may not guarantee full immunity in all cases. People either 
previously diagnosed with COVID-19 or not should be taking the same precautions to avoid SARS-CoV-2 infection. The implications of reinfections are a currently important topic in phase III of the research in vaccines' application.

\section{Acknowledgements}

To MINCIENCIAS-Colombia. To the University of Cordoba.

\section{Authors' contributions}

All authors contributed equally to the manuscript's concept, design of the study, collection, analysis, and interpretation of the data. Besides, all authors did review the paper and approved it before submit it. WN, HM, collected epidemiological data. SM, AF, RR, HS analyzed the data and edited the manuscript. All authors read and approved the final manuscript.

\section{Funding}

None.

\section{Availability of data and materials}

No apply.

\section{Ethics approval and consent to participate}

The study follows the ethical standards of the Ministry of Health of Colombia Resolution No. 8430 of 1993. The present study data correspond to one patient coded under strict anonymity with an internal laboratory number. This study is the results of a research project that was approved by the Comite de ética del Instituto de Investigaciones Biológicas del Trópico de la Universidad de Cordoba, with the number N ${ }^{\circ}$ 0410- 2020.

\section{Consent for publication}

All people involved in the research approved the publication.

\section{Competing interests}

The authors declare no competing interests.

\section{Author details}

${ }^{1}$ Secretaria de Salud del Vaupes, Mitu, Colombia. ${ }^{2}$ Universidad de Cordoba, Instituto de Investigaciones Biologicas del Tropico, Monteria, Colombia.

Received: 4 November 2020 Accepted: 17 December 2020 Published online: 12 January 2021
References

1. European Centre for Disease Prevention and Control. Reinfection with SARS-CoV-2 : considerations for public health response. ECDC [Internet]. 2020 [cited 2020 Oct 30];(September). Available from: https://www.ecdc. europa.eu/sites/default/files/documents/Re-infection-and-viral-shedd ing-threat-assessment-brief.pdf.

2. Seow J, Graham C, Merrick B, Acors S, Steel KJA, Hemmings O, et al. Longitudinal evaluation and decline of antibody responses in SARS-CoV-2 infection. MedRxiv. 2020. https://doi.org/10.1101/2020.07.09.20148429.

3. Liu A, Wang W, Zhao X, Zhou X, Yang D, Lu M, et al. Disappearance of antibodies to SARS-CoV-2 in a -COVID-19 patient after recovery. Clin Microbiol Infect. 2020. https://doi.org/10.1016/j.cmi.2020.07.009.

4. Long QX, Tang XJ, Shi QL, Li Q, Deng HJ, Yuan J, et al. Clinical and immunological assessment of asymptomatic SARS-CoV-2 infections. Nat Med. 2020;26(8):1200-4.

5. Misra-Hebert AD, Jehi L, Ji X, Nowacki AS, Gordon S, Terpeluk P, et al. Impact of the COVID-19 Pandemic on Healthcare Workers' Risk of Infection and Outcomes in a Large, Integrated Health System. J Gen Intern Med. 2020;35(11):3293-301.

6. Ramírez JD, Florez C, Muñoz M, Hernández C, Castillo A, Gomez S, et al. The arrival and spread of SARS-CoV-2 in Colombia. J Med Virol. 2020. https://doi.org/10.1002/jmv.26393.

7. Nascimento VA Do, Corado A de LG, Nascimento FO Do, da Costa ÁKA, Duarte DCG, Luz SLB, et al. Genomic and phylogenetic characterisation of an imported case of sars-cov- 2 in amazonas state, brazil. Mem Inst Oswaldo Cruz. 2020;115(8):1-6. https://www.fda.gov/media/134922/ download.

8. Laiton-Donato K, Villabona-Arenas CJ, Usme-Ciro JA, Franco-Muñoz C, Álvarez-Díaz DA, Villabona-Arenas LS, et al. Genomic Epidemiology of Severe Acute Respiratory Syndrome Coronavirus 2. Colombia Emerg Infect Dis. 2020;26(12):2854-62.

9. Tillett RL, Sevinsky JR, Hartley PD, Kerwin H, Crawford N, Gorzalski A, Laverdure C, Verma SC, Rossetto CC, Jackson D, Farrell MJ, Van Hooser S, Pandori M. Genomic evidence for reinfection with SARS-CoV-2: a case study. Lancet Infect Dis. 2020;3099(20):1-7. https://doi.org/10.1016/S1473 -3099(20)30764-7.

\section{Publisher's Note}

Springer Nature remains neutral with regard to jurisdictional claims in published maps and institutional affiliations.
Ready to submit your research? Choose BMC and benefit from:

- fast, convenient online submission

- thorough peer review by experienced researchers in your field

- rapid publication on acceptance

- support for research data, including large and complex data types

- gold Open Access which fosters wider collaboration and increased citations

- maximum visibility for your research: over 100M website views per year

At BMC, research is always in progress.

Learn more biomedcentral.com/submissions 